\title{
ERROR ANALYSIS TERHADAP KARANGAN NARASI MAHASISWA SEMESTER 3 JURUSAN BAHASA,KOMUNIKASI DAN PARIWISATA POLITEKNIK NEGERI JEMBER
}

\author{
Oleh : \\ CHOLIMATUS ZUHRO *)
}

\begin{abstract}
ABSTRAK
Penelitian ini bertujuan untuk mendeskripsikan kesalahan- kesalahan umum pada karangan narasi yang dibuat mahasiswa bahasa Inggris semester 3 pada Jurusan Bahasa, Komunikasi dan Pariwisata Politeknik Negeri Jember. Metode penelitian ini menggunakan metode deskriptif analisis dengan menggunakan pendekatan kuantitatif, yaitu hasil penelitian yang kemudian diolah dan dianalisis untuk kemudian diambil kesimpulannya. Penelitian ini penelitian populasi dikarenakan obyek penelitian ini adalah seluruh Mahasiswa Jurusan bahasa, Komunikasi dan Pariwisata Politeknik Negeri Jember Angkatan Tahun 2011-2012 yang berjumlah 32 orang. Sedangkan instrumen untuk pengambilan data yang digunakan dalam penelitian ini adalah take home assignment yang berupa karangan narasi mahasiswa dengan topic vocation yang terjadi di masa lalu sehingga menerpkan kaidah masa lampau (past tense). Prosedur aanalisis kesalahan dengan menggunakan tahapan-tahapan. 1. Collecting errors data, 2. Identifying error data, 3. Classifying errors data, dan 4, evaluating errors data atu analisis error data. Analisis data yang digunakan dalam penelitian ini adalah metode quantitative statistical. Analisa ini menghitung prosentase kesalahan -kesalahan yang dibuat mahasiswa dalam karanagan narasinya.Dari hasil penelitian ditemukan kesalahan-kesalan yang dibuat mahasiswa dalam karangan narasinya sebanyak 137, yang meliputi ommision 23\%, Double Marking $17 \%$, regulation/overgeneralization $4 \%$, misformation $27 \%$, archiform $9 \%$, misordering $6 \%$, kategori penggunaan kata sandang $8 \%$ dan interlingual errors $6 \%$. Berdasarkan data tersebut, dapat disimpulkan bahwa kesalahan-kesalahan yang paling banyak dibuat mahasiswa adalah kesalahan intralingual, yaitu kesalahan yang berkaitan dengan kompeten mahasiswa yang dikarenakan ketidakmampuannya dikarenakan oleh kerumitan bahasa target tersebut. Dari hasil dan pembahasan penelitian ini, peneliti dapat memberi saran pada pengajar bahasa Inggris untuk mengajarkan bahasa Inggris tidak hanya dengan penjelasan-penjelasan saja, tetapi harus digabungkan dengan metode comunicative and experiences pada siatuasi pembelajar bahasa target.
\end{abstract}

Kata Kunci: Error Analysis, Karangan Narasi Mahasiswa

\section{Latar Belakang}

Sejak abad ke 20, penelitian akan pembelajaran bahasa mulai banyak dilakukan oleh para ahli bahasa terapan yang terfokus pada perbandingan dua bahasa yang berbeda atau disebut dengan Contrastive Analysis Hypotesis (CAH). Contrastive Analysis Hypotesis (CAH) merupakan theory yang dilandaskan pada pemikiran behaviorist yang menyatakan bahwa bahasa kedua merupakan hasil perkembangan dari kebiasaan-kebiasaan. Meskipun masih banyak kelemahannya, akan tetapi $\mathrm{CAH}$ telah banyak memberikan kontribusi terhadap pengembangan pengajaran bahasa dan juga telah membuka jalan pada penelitian yang lebih luas cakupannya tentang kesalahan (errors) yang dibuat pembelajar bahasa asing yaitu Error Analysis.

Pada dasarnya CAH digunakan untuk menganalisis kesalahan yang mencerminkan adanya interferensi bahasa pertama ke dalam bahasa yang sedang di pelajari atau bahasa target. Sedangkan Error analysis digunakan untuk menganalisis kesalahan dalam bahasa kedua atau bahasa target. Error Analysis (EA) atau analisis kesalahan menjadi populer pada tahun 1965 an. Teori ini meneliti secara mendalam terhadap kesalahan-kesalahan yang ditemukan dalam pembelajaran bahasa target dan mencari tahu sebab-sebab terjadi kesalahan yang dibuat. Error analysis dilaksanakan dengan menganalisis wacana pembelajar baik lesan maupun tulisan. Kemudian kemudian mengidentifikasai kesalahan yang ada dan dikelompokkan dalam jenis kesalahan dan selanjutnya dihitung frekuensinya. Kesalahan yang mempunyai frekuensi tinggi dikategorikan sebagai unsur bahasa yang sukar dipelajarai atau dipahami, sebaliknya kesalahan 
yang mempunyai frekuensi rendah dianggap sebagai hal yang mudah.

Dalam masa ini penelitian tentang error analysis yang dibuat pembelajar bahasa masih dianggap relevan karena error analysis telah terbukti berhasil membuka wawasan tentang pemerolehan bahasa yang merangsang perubahahan praktik mengajar. Kontribusinya adalah adanya penemuan yang membuktikan bahwa mayoritas kesalahan tata-bahasa yang dibuat pembelajar bahasa target tidak mencerminkan bahasa pertama pembelajar melainkan seperti kesalahan tata-bahasa yang dibuat oleh anak-anak yang sedang mempelajari bahasa pertamanya. Seperti dalam bukunya Dulay, Burt and Krashen (1982:138) " Perhaps its most controversial contribution has been the discovery that the majority of grammatical errors second language learner make do not reflect the learner's mother tonguae but are very much like those the young children make as the learn a first language".

Penelitian ini ingin membuktikan bahwa dari sejumlah kesalahan yang dibuat oleh Mahasiswa Jurusan Bhasa, Komunikasi dan Pariwisata Politeknik Negeri Jember Semester 3 pada mata kuliah writing 2 (dalam bahasa Inggris) mayoritas tidak mencerminkan bahasa pertama pembelajar (dalam bahasa Indonesia).

Penelitian ini diharapkan mempunyai kegunaan dan manfaat baik bagi peneliti sendiri sebagai salah satu dosen pengampu mata kuliah writing sebagai pemberian umpan balik yang positif terhadap kesalahan tersebut dan memberikan perlakuan yang tepat, Maupun bagi pengembangan pengetahuan tentang pendidikan yang bisa dimanfaatkan sebagai landasan dalam pengembangan praktek mengajar khususnya dalam mata kuliah writing.

\section{Kajian Teoritis \\ Analisis Kesalahan}

Membuat suatu kesalahan dalam belajar adalah suatu hal yang biasa dan sangat wajar. Dikarenakan dengan adanya kesalahan itulah yang menunjukkan bahwa seseorang sedang belajar. Suatu kesalahan akan memberikan pelajaran bagi seorang siswa untuk mencari yang benar sekaligus berusaha untuk menghindari kesalahan yang sama di masa yang akan datang. Jadi suatu kesalahan adalah merupakan pelajaran yang bermanfaat, dan bukannya hal yang sia-sia.

Seiring dengan pendapat di atas, maka kesalahan sangat diperhitungkan sebagai suatu hal yang sangat penting dalam proses belajar. Apabila kesalahan tersebut di analisis secara cermat, akan membantu pemahaman terhadap permasalahan yang dihadapi. Corder mengatakan “a learner's errors are significant in (that) they provide the researcher evidence of how language is learned or acquired, what strategies or procedures the learner is employing in the discovery of the language" (Kesalahan-kesalahan seorang siswa adalah sangat penting dalam hal bahwa keslahan-kesalahan tersebut memberikan petunjuk kepada peneliti tentang bagaimana bahasa dipelajari atau dikuasai, strategi atau prosedur apa yang digunakan oleh si pelajar dalam upaya mendapatkan bahasa tersebut) (Corder, 1967:167)

\section{Prosedur Analisis Kesalahan}

Dalam proses analisis kesalahan perlu ditentukan lebih dahulu prosedur yang tepat untuk menganalisa kesalahan tersebut. Secara garis besar prosedur yang ditempuh untuk menganalisis kesalahan mencakup empat tahap, yaitu:

1. Collecting errors data Mengumpulkan kesalahan-kesalahan bahasa yang di buat mahasiswa dalam karangan mereka.

2. Identyfying Errors data Mengidentifikasi kesalahan bahasa yang dibuat mahasiswa dalam karangannya.

3. Classifying Errors data Penentuan Sumber kesalahan.

4. Evaluating Errors data

Analisis data yang digunakan dalam penelitian ini adalah metode quantitative statistical. Disini, data yang didapatkan kemudian dianalisa dengan menggunakan rumus, yaitu:

$$
E=\frac{n}{N} \times 100 \%
$$

Penjelasan

$\mathrm{E}=$ prosentase dari setiap kesalahan yang dibuat mahasiswa

$\mathrm{n}=$ jumlah kesalahan dari setiap komponen error yang dibuat mahasiswa $\mathrm{N}=$ jumlah dari keseluruhan errors yang dibuat oleh seluruh mahasiswa (adapted from Ali 1987:186)

\section{Identifikasi Kesalahan}

Burt dan Kiparski (1972) mengembangkan taxonomy kategori linguistik (linguistic category taxonomy) untuk mengklasifikasikan ribuan kesalahan yang dibuat oleh siswa-siswa yang sedang belajar bahasa Inggris di negara asing atau di lingkungannya sendiri. Salah satu modelnya disebut taxonomi strategi luaran (surface strategy taxonomy) yang dikutip dalam Dulay, Burt dan Krashen (1982:150154) sebagai berikut: 
Taxonomi strategi luaran menyoroti bagaimana struktur permukaan kalimat dirubah oleh pembelajar dengan cara:

1. Mengurangi

2. Menambah

3. Melakukan salah bentuk

4. Melakukan kesalahan menyusun

Para peneliti telah menemukan adanya elemen luaran yang dirubah oleh pembelajar secara sistematik dan spesifik. Beberapa kesalahan-kesalahan umum yang ditemukan pada tulisan pembelajar bahasa asing adalah:

\section{Double Marking}

Masuk dalam kategori kesalahan addition, yaitu kesalahan dalam penambahan karena kegagalan dalm menghilangkan salah satu bagian dalam linguistik. Dalam bahasa Inggris, ciri semantik dalam kalimat past tense ditandai dengan perubahan kata kerja. Tetapi apabila kata kerja bantu did/didn't maka kata kerjanya harus kembali seperti kata kerja pertama.

\section{Regularization}

Ini juga termasuk dalam kategori kesalahan addition, yaitu suatu kaidah yang khusus diterapkan secara umum pada bentuk kata kerja maupun kata benda. Kata kerja study dan learn akan berubah menjadi studied dan learned. Teatpi kata kerja eat apabila dirubah menjadi bentuk lampau tidak menjadi eated tetapi ate. Kata benda sheep tetap sheep dalam bentuk jamak, bukan sheeps. Sheeps dan eated adalah bentuk regulation.

\section{Misinformation}

Kesalahan ini ditandai oleh bentuk morfem atau struktur yang salah. Dalam ommision, tidak ada penambahan sama sekali, sedangkan dalam misinformation ada penambahan tetapi salah.

\section{Archi-form}

Pemilihan satu bentuk untuk merepresentasikan bentuk lain. Pembelajar kadang-kadang memilih kata keterangan demonstratif this, that, these dan those, tetapi tidak memperhatikan aturan penggunaannya. Contohnya That dog menhjadi that dogs (seharusnya those dogs).

\section{Misordering}

Keslahan ini ditandai oleh letak kesalahan letak morfem atau sekelompok morfem dalam ujaran. Contohnya $\mathrm{He}$ is all the time late (seharusnya $\mathrm{He}$ is late all the time)

Interlingual errors

Kesalahan ini ditandai oleh struktur frasa atau kalimat yang mencerminkan struktur bahasa pertama pembelajar. Dulay, burt dan Krashen
(1982: 171) memberi contoh frasa "the man skinny" yang dibuat oleh seorang penutur asli bahasa Spanyol yang sedang belajar bahasa Inggris. Frase tersebut mencerminkan kaidah frase bahasa Spanyol yaitu dalam frase "el hombre flaco".

\section{Ambiguous error}

Dulay, Burt and Krashen (1982 :172) mendefisinikan ambiguous errors adalah " kesalahan yang dibuat pembelajar yang mencerminkan bahasa pertama pembelajar juga mencerminkan kaidah bahasa perkembangan yaitu bahasa yang digunakan oleh anak-anak yang belajar bahasa Inggris sebagai bahasa pertama. Contohnya "I have no car" yang dibuat oleh penutur asli bahasa Spanyol. Kontruksi negatif dalam kalimat ini mencerminkan kaidah bahasa Spanyol dan kontruksi ini juga mencerminkan ciri ujaran anak-anak yang sedang belajar bahasa Inggris sebagai bahasa pertama.

\section{Penentuan Sumber Kesalahan}

Kesalahan- kesalahan yang telah diidentifikasi kemudian dideskripsikan dalam bentuk tabel. Dari kesalahan tersebut masingmasing tabel akan mengandung deskripsi kesalahan dan jumlah kesalahan. Berdasarkan sumber kesalahan (error sources), kesalahan dapat digolongkan menjadi empat sumber kesalahan utama (Brown, 1980:172). Sumber kesalahan tersebut adalah:

1. Interlingual transfer (pengalihan antar bahasa)

2. Intralingual transfer (pengalihan intra bahasa)

3. Konteks belajar, dan

4. Strategi Komunikasi

Interlingual transfer sering terjadi pada tahap awal belajar bahasa asing, pada waktu bahasa ibu masih menjadi satu-satunya sistem bahasa yang dikenal, sehingga sering terjadi kerancuan antar dua bahasa tersebut. Dalam intralingual transfer sumber kesalahan berasal dari bahasa yang sedang dipelajari itu sendiri. Hal ini bisa terjadi apabila pelajar melakukan generalisasi yang keliru setelah belajar beberapa lama.

\section{Metodologi Penelitian}

Dalam penelitian ini, metode yang digunakan bertujuan untuk mendeskripsikan Error Analysis terhadap karangan narasi Mahasiswa Semester 3 Jurusan Bahasa, Komunikasi dan Pariwisata Politeknik Negeri Jember. Data yang didapatkan akan dianalisis dengan formula prosentase kemudian akan dikonsultasikan dengan menggunakan kualifikasi dari interpretasi kesalahan-kesalahan mahasiswa. 
Populasi penelitian ini adalah seluruh Mahasiswa Semester 3 Angakatan tahun 20112012, Jurusan Bahasa, Komunikasi dan Pariwisata Politeknik Negeri Jember yang sedang menempuh kuliah writing 2 yang berjumlah 32 orang. Penelitian ini dilaksanakan pada Semester Genap 2013-2014

Teknik yang digunakan dalam penelitian ini untuk pengumpulan data adalah dengan cara memberikan take home assignment, yaitu tugas kepada mahasiswa yang berupa membuat karangan narasi dalam bahasa Inggris dengan topik tentang liburan minggu lalu dengan penerapan kaidah masa lampau (past tense). Panjang karangan antara 100-150 kata. Mereka mengerjakan di rumah, sehingga mereka memiliki cukup waktu untuk mengerjakannya. Dengan cara ini diharapkan mereka mampu menunjukkan segala kemampuan yang ada untuk menyelesaikan tugas yang diberikan.

Data yang telah terkumpul dalam bentuk karangan, kemudian dianalisa lebih lanjut. Analisa dilakukan dengan berpedoman pada prosedur sebagaimana diterangkan pada bab 2 mengenai kerangka teori diatas. Dalam hal ini kesalahan yang mula-mula diidentifikasi, diklasifikasikan menurut jenis kesalahannya dan kemudian dideskripsikan dalam bentuk tabel. Dari tabel tersebut akan terlihat prosentase kesalahan dan tingkat kemampuan mahasiswa dalam mengarang narasi dalam bahasa Inggris.
Sedangkan pada tahap akhir analisis adalah penentuan sumber kesalahan. Dalam hal ini peneliti berusaha menentukan sumber kesalahan tersebut apakah berasal dari interlingual transfer, intralingual transfer. Analisis data yang digunakan dalam penelitian ini adalah metode quantitative statistical. Disini, data yang didapatkan kemudian dianalisa dengan menggunakan rumus, yaitu:

$$
\mathrm{E}=\frac{\mathrm{n}}{\mathrm{N}} \mathrm{x} 100 \%
$$

Penjelasan

$\mathrm{E}=$ prosentase dari setiap kesalahan yang dibuat mahasiswa

$\mathrm{n}=$ jumlah kesalahan dari setiap komponen error yang dibuat mahasiswa

$\mathrm{N}=$ jumlah dari keseluruhan errors yang dibuat oleh seluruh mahasiswa

(adapted from Ali 1987:186)

\section{Hasil \\ Dari 32 mahasiswa sebagai obyek dari penelitian ini, akhirnya terkumpul 32 lembar karangan narasi yang menjadi data primer penelitian ini. Karangan narasi tersebut kemudian diteliti dan dianalisis. Dari data yang terkumpul ditemukan sebanyak 137 kesalahan- kesalahan yang dibuat mahasiswa. Setelah diidentifikasi secara teliti kemudian kesalahan-kesalahan tersebut dirinci dan diklasifikasi berdasarkan taxonomi kategori linguistik (linguistic category taxonomy)}

Tabel 1. Jenis Kesalahan dan Kode.

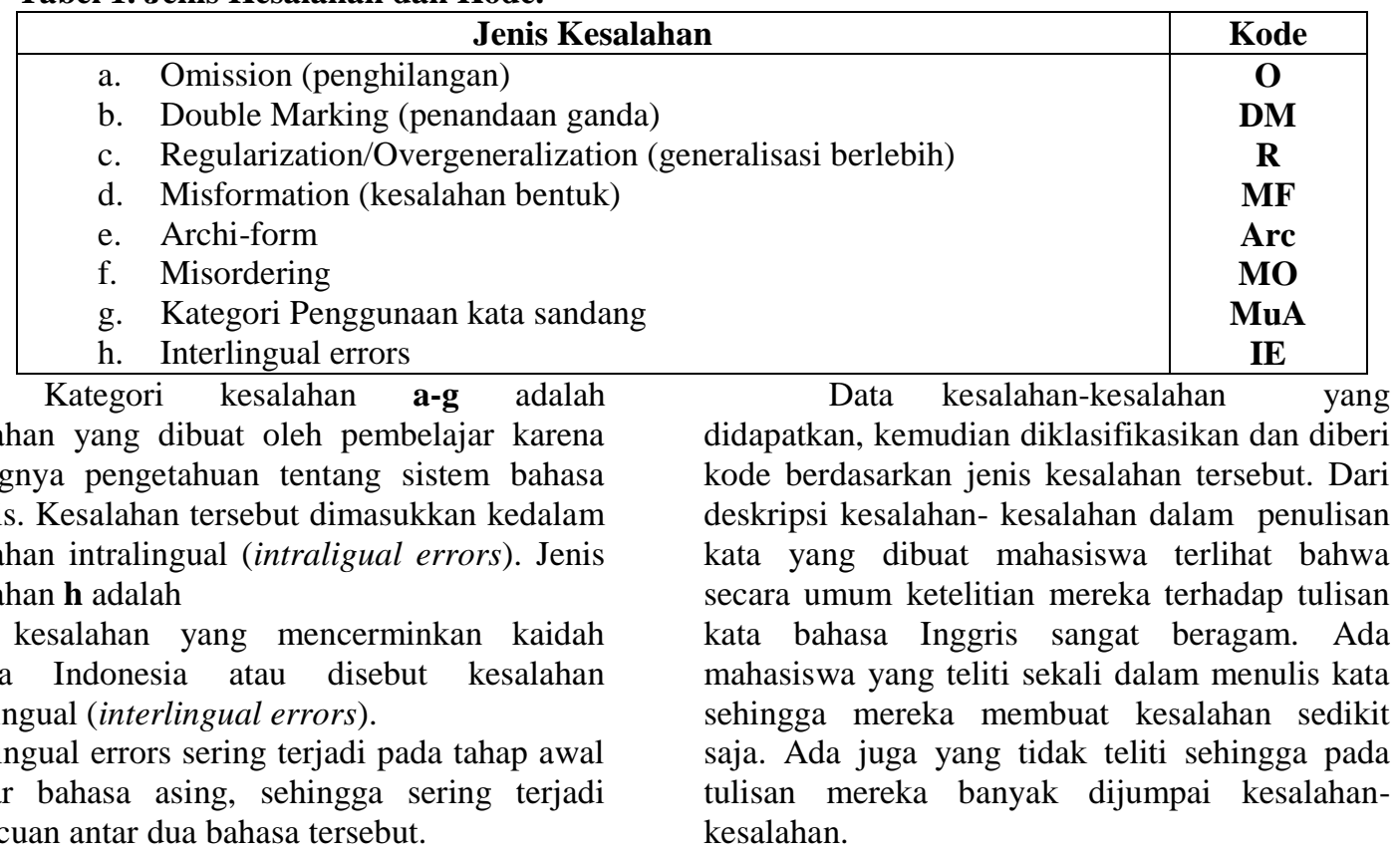

kerancuan antar dua bahasa tersebut.

kesalahan.

Tabel 2. Pengkodean dan Klasifikasi data 


\begin{tabular}{|c|c|c|c|c|c|c|c|c|c|}
\hline No & Error data & $\mathbf{O}$ & DM & $\mathbf{R}$ & MF & Arc & MO & MuA & IE \\
\hline 1 & Who is knocking _ the door & $\sqrt{1}$ & & & & & & & \\
\hline 2 & Nina entered the $\quad$ room & $\sqrt{ }$ & & & & & & & \\
\hline $\begin{array}{l}3 \\
4 \\
5\end{array}$ & $\begin{array}{l}\text { Last week my older sister invite me, } \\
\text { so we go to surabaya to visited her }\end{array}$ & & & $\sqrt{ }$ & $\begin{array}{l}\sqrt{V} \\
\sqrt{ }\end{array}$ & & & & \\
\hline $\begin{array}{l}6 \\
7\end{array}$ & $\begin{array}{l}\text { Therefore Malang has beachs are } \\
\text { beautiful, there are balek kambang } \\
\text { and ngliyep }\end{array}$ & & & $\sqrt{ }$ & & $\sqrt{ }$ & & & \\
\hline $\begin{array}{l}8 \\
9\end{array}$ & $\begin{array}{l}\text { I eated some fish and make a fried } \\
\text { chicken was very interesting }\end{array}$ & & & & $\begin{array}{l}\sqrt{ } \\
\sqrt{ }\end{array}$ & & & & \\
\hline $\begin{array}{l}10 \\
11\end{array}$ & $\begin{array}{l}\text { It was my tradition and __ done } \\
\text { every year }\end{array}$ & $\sqrt{1}$ & & & $\sqrt{ }$ & & & & \\
\hline $\begin{array}{l}12 \\
13 \\
14 \\
15\end{array}$ & $\begin{array}{l}\text { After I done it I done good } \\
\text { relationship with my } \\
\text { neighbourhood }\end{array}$ & $\sqrt{ }$ & & & $\begin{array}{l}\sqrt{ } \\
\sqrt{ } \\
\sqrt{ } \\
\sqrt{ }\end{array}$ & & & & \\
\hline $\begin{array}{l}16 \\
17\end{array}$ & $\begin{array}{l}\text { I meet my uncle and aunt whom } \\
\text { never met me }\end{array}$ & & & & $\sqrt{ }$ & $\sqrt{ }$ & & & \\
\hline No & Error data & $\mathbf{O}$ & DM & $\mathbf{R}$ & MF & Arc & MO & MuA & IE \\
\hline $\begin{array}{l}18 \\
19 \\
20 \\
21\end{array}$ & $\begin{array}{l}\text { I invited to Watu ulo and Puger } \\
\text { with my cousin so I known many } \\
\text { kind of fish }\end{array}$ & $\sqrt{ }$ & & & $\begin{array}{l}\sqrt{1} \\
\sqrt{ }\end{array}$ & $\sqrt{ }$ & & & \\
\hline $\begin{array}{l}22 \\
23\end{array}$ & $\begin{array}{l}\text { I didn't fell that I had been spent } \\
\text { my holyday }\end{array}$ & & $\sqrt{ }$ & & $\sqrt{ }$ & & & & \\
\hline $\begin{array}{l}24 \\
25\end{array}$ & I spent the latest night to played & & & & $\begin{array}{l}\sqrt{ } \\
\sqrt{ }\end{array}$ & & & & \\
\hline $\begin{array}{l}26 \\
27\end{array}$ & $\begin{array}{l}\text { after I arrived to my house, I } \\
\text { cleaned and sweaped } \\
\text { my house. }\end{array}$ & & & & $\sqrt{ }$ & $\sqrt{ }$ & & & \\
\hline 28 & $\begin{array}{l}\text { In the night there were many guest } \\
\text { came to my house }\end{array}$ & $\sqrt{ }$ & & & & & & & \\
\hline $\begin{array}{l}29 \\
30 \\
31\end{array}$ & $\begin{array}{l}\text { The day that is always waited in } \\
\text { every year and also be identified } \\
\text { with }\end{array}$ & & & & $\sqrt{ }$ & & $\sqrt{ }$ & & $\sqrt{ }$ \\
\hline 32 & Reached in Madiun & & & & $\sqrt{ }$ & $\sqrt{ }$ & & & \\
\hline 33 & This is my uncle house & $\sqrt{1}$ & & & & & & & \\
\hline 34 & $\begin{array}{l}\text { I was usually celebrated my } \\
\text { birthday }\end{array}$ & & & & & & $\sqrt{ }$ & & \\
\hline $\begin{array}{l}35 \\
36\end{array}$ & $\begin{array}{l}\text { I was spend my holidays in my } \\
\text { grandfather house }\end{array}$ & $\sqrt{ }$ & & & $\sqrt{ }$ & & & & \\
\hline $\begin{array}{l}37 \\
38 \\
\end{array}$ & I am very enjoyed the vocation & & $\sqrt{ }$ & & & & & & $\sqrt{ }$ \\
\hline $\begin{array}{l}39 \\
40 \\
41\end{array}$ & $\begin{array}{l}\text { I m very enjoy the holidays in my } \\
\text { friend cottage }\end{array}$ & $\sqrt{ }$ & $\sqrt{ }$ & & & & & & $\sqrt{ }$ \\
\hline $\begin{array}{l}42 \\
43\end{array}$ & $\begin{array}{l}\text { I waste my time with eat and } \\
\text { watching film }\end{array}$ & & & & $\sqrt{ }$ & $\sqrt{ }$ & & & \\
\hline No & Error data & $\mathbf{O}$ & DM & $\mathbf{R}$ & MF & Arc & MO & MuA & IE \\
\hline $\begin{array}{l}44 \\
45 \\
46\end{array}$ & I am enjoy the journey by car & & $\sqrt{ }$ & & $\sqrt{ }$ & $\sqrt{ }$ & & & \\
\hline $\begin{array}{l}47 \\
48\end{array}$ & There too much people & $\sqrt{1}$ & & & & $\sqrt{ }$ & & & \\
\hline 49 & My friend is affraid _ the dog & $\sqrt{ }$ & & & & & & & \\
\hline 50 & The teacher discuss the _trip & $\sqrt{1}$ & & & & & & & \\
\hline
\end{tabular}

*) Staf Pengajar Jurusan Bahasa,Komunikasi dan Pariwisata, Politeknik Negeri Jember 
Cholimatus Zuhro, Error Analysis Terhadap Karangan Narasi Mahasiswa Semester 3 Jurusan Bahasa,Komunikasi Dan Pariwisata Politeknik Negeri Jember

\begin{tabular}{|c|c|c|c|c|c|c|c|c|c|}
\hline 51 & $\begin{array}{l}\text { After the trip they attended ___ their } \\
\text { work }\end{array}$ & $\sqrt{1}$ & & & & & & & \\
\hline $\begin{array}{l}52 \\
53\end{array}$ & $\begin{array}{l}\text { The techers has many cases to } \\
\text { solving }\end{array}$ & & & & $\sqrt{ }$ & & & & $\sqrt{ }$ \\
\hline 54 & Using of electricity & & & & & & & & $\sqrt{ }$ \\
\hline 55 & Nuna didn't saw the woman & & $\sqrt{ }$ & & & & & & \\
\hline 56 & I didn't wet to the beach & & $\sqrt{ }$ & & & & & & \\
\hline 57 & She doesn't knows my name & & $\sqrt{ }$ & & & & & & \\
\hline 58 & He didn't liked the breakfast & & $\sqrt{ }$ & & & & & & \\
\hline 59 & That books were very interesting & & & & & $\sqrt{ }$ & & & \\
\hline 60 & There were many childs & & & & $\sqrt{ }$ & & & & \\
\hline 61 & This boys are very nice & & & & & $\sqrt{ }$ & & & \\
\hline 62 & I met there some tourist & $\sqrt{1}$ & & & & & $\sqrt{ }$ & & \\
\hline 63 & I don't know what is that & & & & & & $\sqrt{ }$ & & \\
\hline 64 & I felt loneliness at that night & & & & $\sqrt{ }$ & & & & $\sqrt{ }$ \\
\hline $\begin{array}{l}65 \\
66 \\
\end{array}$ & $\begin{array}{l}\text { At there we visited our family } \\
\text { which have a new car }\end{array}$ & & & & & $\sqrt{ }$ & & & $\sqrt{ }$ \\
\hline $\begin{array}{l}67 \\
68 \\
69\end{array}$ & $\begin{array}{l}\text { After that I and my family go to my } \\
\text { grandparent house }\end{array}$ & $\sqrt{ }$ & & & $\sqrt{ }$ & & & & $\sqrt{ }$ \\
\hline 70 & I went with a car & & & & & $\sqrt{ }$ & & $\sqrt{ }$ & \\
\hline & & & & & & & & & \\
\hline $\begin{array}{l}71 \\
72 \\
\end{array}$ & $\begin{array}{l}\text { In the next day, we go to our } \\
\text { another friend home }\end{array}$ & & & & & $\sqrt{ }$ & & & $\sqrt{ }$ \\
\hline 73 & My sister live in malang & $\sqrt{1}$ & & & & & & & \\
\hline 74 & She like rujak soto & $\sqrt{1}$ & & & & & & & \\
\hline $\begin{array}{l}75 \\
76\end{array}$ & She was all the time play volleyball & $\sqrt{ }$ & & & & & $\sqrt{ }$ & & \\
\hline 77 & He didn't came last night & & $\sqrt{ }$ & & & & & & \\
\hline 78 & My grandfather didn't slept well & & $\sqrt{ }$ & & & & & & \\
\hline 79 & $\begin{array}{l}\text { There are many peoples in the } \\
\text { beach }\end{array}$ & & & $\sqrt{ }$ & & & & & \\
\hline $\begin{array}{l}80 \\
81\end{array}$ & My mother need a scissor to cut & $\sqrt{1}$ & & $\sqrt{ }$ & & & & & \\
\hline 82 & There are so many good news & & & $\sqrt{ }$ & & & & & \\
\hline 83 & They didn't belived me & & $\sqrt{ }$ & & & & & & \\
\hline 84 & She was watched a good film & & $\sqrt{ }$ & & & & & & \\
\hline 85 & Film of arnold __very excited & $\sqrt{1}$ & & & & $\sqrt{ }$ & & & \\
\hline 86 & They noisily shot__pistols & & & & & $\sqrt{ }$ & & & \\
\hline 87 & After that we come to drink & & & & & & & & $\sqrt{ }$ \\
\hline 88 & They didn't answered my call & & $\sqrt{ }$ & & & & & & \\
\hline 89 & $\begin{array}{l}\text { My father didn't went to beach } \\
\text { with me }\end{array}$ & & $\sqrt{ }$ & & & & & & \\
\hline 90 & I myself finished my work & & & & & & $\sqrt{ }$ & & \\
\hline 91 & He live hapily & $\sqrt{1}$ & & & & & & & \\
\hline 92 & Before going to _ beach & & & & & $\sqrt{ }$ & & & \\
\hline No & Error data & $\mathbf{O}$ & DM & $\mathbf{R}$ & MF & Arc & MO & MuA & IE \\
\hline 93 & When she came here, I was sleep & & $\sqrt{ }$ & & & & & & \\
\hline $\begin{array}{l}94 \\
95 \\
\end{array}$ & $\begin{array}{l}\text { We has enough money to watch__ } \\
\text { concert }\end{array}$ & & & & $\sqrt{ }$ & & & $\sqrt{ }$ & \\
\hline 96 & $\begin{array}{l}\text { Thi s novel is write by my favourite } \\
\text { author }\end{array}$ & & & & $\sqrt{ }$ & & & & \\
\hline 97 & They goes to malang at weekend & & & & $\sqrt{ }$ & & & & \\
\hline $\begin{array}{l}98 \\
99 \\
100\end{array}$ & $\begin{array}{l}\text { We have finish our homework } \\
\text { before go out __ dinner }\end{array}$ & $\sqrt{ }$ & & & $\begin{array}{l}\sqrt{ } \\
\sqrt{ }\end{array}$ & & & & \\
\hline
\end{tabular}




\begin{tabular}{|c|c|c|c|c|c|c|c|c|c|}
\hline 101 & She didn't wore much make up & & $\sqrt{ }$ & & & & & & \\
\hline 102 & He also felt she _ energetic & $\sqrt{t}$ & & & & & & & \\
\hline 103 & She was _ good girl & & & & & & & $\sqrt{ }$ & \\
\hline 104 & The boys are my uncle's sons & & $\sqrt{ }$ & & & & & & \\
\hline 105 & $\begin{array}{l}\text { we need __ hour to finish the } \\
\text { exercise }\end{array}$ & & & & & & & $\sqrt{ }$ & \\
\hline 106 & This magazines are my mother's & & & & & $\sqrt{ }$ & & & \\
\hline $\begin{array}{l}107 \\
108\end{array}$ & he gived me a beautiful given & & & & $\begin{array}{l}\sqrt{ } \\
\sqrt{ }\end{array}$ & & & & \\
\hline 109 & The boys say to me lastnight & & & & $\sqrt{ }$ & & & & \\
\hline 110 & I did went to __ beach & & $\sqrt{ }$ & & & & & $\sqrt{ }$ & \\
\hline $\begin{array}{l}111 \\
112 \\
\end{array}$ & $\begin{array}{l}\text { As my father didn't permited us to } \\
\text { go to _ beach }\end{array}$ & & $\sqrt{ }$ & & & & & $\sqrt{ }$ & \\
\hline No & Error data & $\mathbf{O}$ & DM & $\mathbf{R}$ & MF & Arc & MO & MuA & IE \\
\hline 113 & It _ very hot yesterday & $\sqrt{1}$ & & & & & & & \\
\hline 114 & $\begin{array}{l}\text { I didn' went to swim because I _- } \\
\text { sick }\end{array}$ & $\sqrt{ }$ & $\sqrt{ }$ & & & & & & \\
\hline 115 & $\begin{array}{l}\text { My grandmother buy some fruits for } \\
\text { me yesterday }\end{array}$ & & & & $\sqrt{ }$ & & & & \\
\hline $\begin{array}{l}116 \\
117\end{array}$ & My friend house __ near the beach & $\begin{array}{l}\sqrt{ } \\
\sqrt{ }\end{array}$ & & & & & & & \\
\hline 118 & That women liked going to swim & & & & & $\sqrt{ }$ & & & \\
\hline 119 & This vegetables are very good & & & & & $\sqrt{ }$ & & & \\
\hline 120 & I went to _ movie & & & & & & & $\sqrt{ }$ & \\
\hline 121 & We didn't went out at night & & $\sqrt{ }$ & & & & & & \\
\hline 122 & I think she will be away a __week & $\sqrt{1}$ & & & & & & & \\
\hline 123 & I late got up this morning & & & & & & $\sqrt{ }$ & & \\
\hline 124 & I get to _office & & & & & & & $\sqrt{ }$ & \\
\hline 125 & We quickly walked & & & & & & $\sqrt{ }$ & & \\
\hline 126 & The building _ built in 1975 & $\sqrt{ }$ & & & & & & & \\
\hline 127 & My sister doesn't plays guitar well & & $\sqrt{ }$ & & & & & & \\
\hline 128 & Sarah cans go out & & & & $\sqrt{ }$ & & & & \\
\hline 129 & $\begin{array}{l}\text { The sun shining when we left the } \\
\text { house }\end{array}$ & $\sqrt{ }$ & & & & & & & \\
\hline 130 & We were walked along the beach & & $\sqrt{ }$ & & & & & & \\
\hline 131 & I were cooking in the kitchen & & & & $\sqrt{ }$ & & & & \\
\hline No & Error data & $\mathbf{O}$ & DM & $\mathbf{R}$ & MF & Arc & MO & MuA & IE \\
\hline 132 & I was climbed up the tree & & $\sqrt{ }$ & & & & & & \\
\hline 133 & Diana start to panic & $\sqrt{1}$ & & & & & & & \\
\hline 134 & My father decided to climb_tree & & & & & & & $\sqrt{ }$ & \\
\hline 135 & I falled out of my bedroom & & & & $\sqrt{ }$ & & & & \\
\hline 136 & They was outside & & & & $\sqrt{ }$ & & & & \\
\hline \multirow[t]{3}{*}{137} & He tried to helped & & & & $\sqrt{ }$ & & & & \\
\hline & Jumlah Kesalahan & $\begin{array}{l}3 \\
\mathbf{1}\end{array}$ & 24 & 5 & 39 & 13 & 8 & 9 & 8 \\
\hline & Total Keseluruhan & & & & & 137 & & & \\
\hline
\end{tabular}

\section{Pembahasan}

Berdasarkan rekapitulasi data pada tabel klsifikasi data kesalahan- kesalahan yang ditulis mahasiswa dalam karangan narasinya, kita dapat mengetahui bahwa dari 32 karangan narasi mahasiswa terdapat 137 kesalahan-kesalahan yang dibuat mahasiswa, dan untuk lebih jelasnya, data tersebut dapat disimpulkan sebagai berikut: 
Cholimatus Zuhro, Error Analysis Terhadap Karangan Narasi Mahasiswa Semester 3 Jurusan

Bahasa,Komunikasi Dan Pariwisata Politeknik Negeri Jember

Tabel 3. Rekapitulasi Jenis Kesalahan yang Dibuat Mahasiswa

\begin{tabular}{|c|c|}
\hline Jenis Kesalahan & Jumlah \\
\hline $\begin{array}{ll}\text { a. } & \text { Omission (penghilangan) } \\
\text { b. } & \text { Double Marking (penandaan ganda) } \\
\text { c. } & \text { Regularization/Overgeneralization (generalisasi berlebih) } \\
\text { d. } & \text { Misformation (kesalahan bentuk) } \\
\text { e. } & \text { Archi-form } \\
\text { f. } & \text { Misordering } \\
\text { g. } & \text { Kategori Penggunaan kata sandang } \\
\text { h. } & \text { Interlingual errors }\end{array}$ & $\begin{array}{c}31 \\
24 \\
5 \\
39 \\
13 \\
8 \\
9 \\
8\end{array}$ \\
\hline
\end{tabular}

Dari rekapitulasi data jenis kesalahan-kesalahan yang dibuat mahasiwa, kemudian data -data tersebut dianalisis menggunakan rumus yang sudah disebutkab dalam Bab 2 dan Bab 3 untuk mengetahui prosentasenya.

\section{a. Omission}

$$
E=\frac{31}{137} 100 \%
$$

b. Double Marking

$$
=23 \%
$$

$$
E=\frac{24}{137} \times 100 \%
$$

$$
=17 \%
$$

\section{c. Regulation/overgeneralazation}

$$
\begin{aligned}
& E=\frac{5}{137} \times 100 \% \\
& =4 \%
\end{aligned}
$$

\section{d. Misformation}

$$
=27 \%
$$

\section{e. Archiform}

$$
\begin{aligned}
& E=\frac{13}{137} \times 100 \% \\
& =9 \%
\end{aligned}
$$

\section{f. Misordering}

$$
\begin{aligned}
& E=\frac{8}{137} \times 100 \% \\
& =6 \%
\end{aligned}
$$

\section{g. Kategori Penggunaan Kata Sandang}

$$
E=\stackrel{9}{x} 100 \%
$$

$$
=8 \%
$$

\section{g. Interlingual Error}

$$
\begin{aligned}
& E=\frac{8}{137} \times 100 \% \\
& =6 \%
\end{aligned}
$$

Dari hasil analisis data jenis kesalahankesalahan yang dibuat mahasiswa dalam karangan narasinya, ditemukan jenis kesalahan-kesalahan ommission sebesar 23\%, Double marking 17\%, regulation/overgeneralization 4\%, misformation $27 \%$, archiform 9\%, misordering 6\%, kategori penggunaan kata sandang $8 \%$ dan interlingual errors 6\%. Dari data ini dapat diketahui bahwa kesalahan-kesalahan yang paling banyak dilakukan mahasiswa dalam karangan narasinya adalah jenis kesalahan Misinformation, yaitu kesalahan yang ditandai oleh bentuk morfem atau struktur yang salah. Bila didalam kesalahan ommision, tidak ada penambahan sama sekali, maka dalam kesalahan misinformation, ada penambahan, tetapi penambahan itu salah atau tidak benar.

Dalam hal ini mahasiswa masih banyak menemui kesulitan dalam membedakan antara kata kerja dan kata benda. Mahasiswa juga mengalami kesulitan dalam menggunakan keduanya dalam kalimat yang benar. Kesalahan-kesalan ini muncul 
dikarenakan kurangnya kemampuan mahasiswa (competence) dalam pembelajaran bahasa. Biasanya kesalahn-kesalahan sperti ini terjadi dan berulang-ulang. Dari data yang diperoleh juga memberi gambaran bahwa mahasiswa masih dperlukan adanya penguatan dalam pembelajaran bahasa, karena dalam pembelajaran bahasa, akan berpengaruh jika pembelajar bahasa memberikan respon secara aktif dan terus-menerus terhadap rangsangan.

Dari data ini juga dapat diketahui bahwa kesalahan-kesalahan intralingual yaitu yang meliputi kesalahan omission, double marking, regulation, misinformation, archiform, misordering, dan penggunaan kata sandang yang besarnya $94 \%$ dari total kesalahan-kesalahan yang dibuat mahasiswa dalam karangan narasinya. Sedangkan kesalahan interlingual, yaitu kesalahan-kesalahan yang dibuat dikarenakan adanya kontak antara dua bahasa sebesar $6 \%$ dari total kesalahan-kesalahan yang dibuat mahasiswa dalam karangan narasinya.

\section{Kesimpulan dan Saran}

Dari hasil penelitian ini dapat disimpulkan bahwa kesalahan-kesalahan dalam penulisan bahasa Inggris yang dibuat mahasiswa pada karangan narasinya yang paling banyak ditemukan adalah jenis kesalahan Intralingual, yaitu kesalahan-kesalahan yang yang terletak pada mahasiswa itu sendiri sebagai pembelajar bahasa target (dalam hal ini bahasa Inggris), yang disebabkan oleh kerumitan sistem bahasa target itu sendiri. Karena ketidak tahuannya/kemampuannya pembelajar itu sendiri, bukan karena terpengaruh sistem bahasa ibu.

Sedangkan untuk kesalahan-kesalahan interlingal errors atau kesalahan-kesalahan yang dipengaruhi oleh bahasa ibu terdapat $6 \%$ dari total keseluruhan kesalahan-kesalahan yang dibuat mahasiswa dalam karangan narasinya, dan ini menunjukkan bahwa interlingual errors terjadi karena adanya kontak bahasa yang terjadi dikarenakan adanya saling pengaruh antara bahasa pertama/ibu dengan bahasa ke dua atau bahasa target yang biasa juga disebut interferensi. Interferensi bahasa ini memberikan kesulitan pada pembelajar dalam mempelajari bahasa target dan sekaligus menjadi sumber kesalahan dalam pembelajaran bahasa.

Dari hasil dan pembahasan penelitian ini, peneliti dapat memberi saran pada pengajar bahasa Inggris untuk mengajarkan bahasa Inggris tidak hanya dengan penjelasan-penjelasan saja, tetapi harus digabungkan dengan metode comunicative and experiences pada siatuasi pembelajar bahasa target. Pembelajar bahasa akan merespon secara aktif terhadap rangsangan-rangsangan yang diberikan. Efek dari rangsangan itu adalah diperlukannya penguatan bagi pembelajar bahasa yang bersangkutan misalnya dengan pujian.

\section{DAFTAR PUSTAKA}

Ali, Muhammad. 1987. Penelitian Pendidikan: Prosedur dan Strategi, Bandung: PT. Angkasa

Arikunto, Suharsimi. 2002. Prosedur Penelitian Suatu Pendekatan Praktek. Jakarta: PT Adi Mahasatya.

Brown, H. D. 2000. Principles of Language Learning and Teaching. Prentice Hall, inc. Englewood Clifffs: New Jersey.

Burt, M.K, and Carol Kiparsky. 1972. The Gooficon: A Repair Manual for English. Massachussets : Newbury House Publishers, Rowley.

Dulay, Heidi, Marina Burt dan Stephen Krashen. 1982. Language two.New York: Oxford University Press. 
Cholimatus Zuhro, Error Analysis Terhadap Karangan Narasi Mahasiswa Semester 3 Jurusan Bahasa,Komunikasi Dan Pariwisata Politeknik Negeri Jember 